\title{
MOSAICOS DE TURQUESA DEL POSCLÁSICO TARDÍO HALLADOS EN OAXACA, MÉXICO
}

\section{LATE POSTCLASSIC TURQUOISE MOSAIC ARTIFACTS FROM OAXACA, MEXICO}

\author{
Robert Markens ${ }^{1}$ \\ rmarkens@hotmail.com \\ Marcus Winter ${ }^{2}$ \\ winteroax@prodigy.net.mx \\ Cira Martínez López ${ }^{2}$ \\ ciramartinez_lopez@hotmail.com
}

\section{RESUMEN}

Los mosaicos de turquesa se han encontrado en varios sitios arqueológicos del Posclásico Tardío en el centro-norte de Oaxaca. Además de objetos de Monte Albán y Zaachila, hay máscaras de la Cueva de Ejutla y Cueva Cheve, escudos de Cueva Cheve y la Cueva de Tenango, una orejera y un malacate de la Cueva de Ejutla, y placas rectangulares de Cueva Cheve. Las teselas sueltas fueron encontradas en la Cueva del Diablo y en Yucuita. En este texto se describen los materiales utilizados en los mosaicos, la función de los artefactos y posibles mecanismos de intercambio para adquirir estos objetos.

Palabras clave: Turquesa, mosaico, tesela, Oaxaca.

1 Investigador, Instituto de Investigaciones Estéticas sede Oaxaca, Universidad Nacional Autónoma de México.

${ }^{2}$ Docente, Instituto Nacional de Antropología e Historia, Centro INAH-Oaxaca. 


\section{ABSTRACT}

Turquoise mosaics have been found in several Late Postclassic archaeological sites in north-central Oaxaca. In addition to objects from Monte Albán and Zaachila, examples include masks from the Cueva de Ejutla and Cueva Cheve, shields from Cueva Cheve and the Cueva de Tenango, an earspool and a spindle whorl from the Cueva de Ejutla, and rectangular plaques from Cueva Cheve. Loose tesserae were found in the Cueva del Diablo near Mitla and at Yucuita in the Nochixtlán Valley. We describe materials used in the mosaics, discuss artifact function and suggest possible exchange mechanisms through which the objects were procured.

Keywords: Turquoise, mosaics, tesserae, Oaxaca.

\section{RESEARCH CONTEXT}

The wooden masks, shields and plaques with turquoise, greenstone and shell mosaic inlays from Oaxaca considered in this study constitute one class of finely crafted objects that were produced, used and exchanged throughout central and southern Mexico and to a lesser degree throughout Mesoamerica during the Late Postclassic period (AD 1200-1521) (POHL, 2012). These items, together with other classes of articles, like some types of pottery, implements carved from bone, jewelry wrought in gold, silver and copper and painted screen-fold books were rendered in what archaeologists and art historians often call the Mixteca-Puebla style (BOONE, 2000; CASO, 1969; ESCALANTE, 2012; GALLEGOS, 1978; MOSER, 1969; NICHOLSON AND QUIÑONES, 1994; SMITH AND BERDAN, 2003). The term International style has also been applied (ROBERTSON, 1959) and draws attention to the fact that people of distinct 
language and identity distributed over a broad area employed this refined style in making these prized goods. Whatever term one chooses to refer to this style, its wide distribution suggests two things: 1) the messages encoded in the objects were shared by ethnically diverse elite groups for whom most of the objects were intended and 2) the origin and distribution of the style may be rooted to some extent in the nature of political organization during the Postclassic period (AD 850-1521).

During the Postclassic period the city-state, or señorio in Spanish, was the nucleus of political organization in most of Oaxaca and Mesoamerica. The average citystate in the Mixteca Alta region of Oaxaca, for example, occupied an area of 310 $\mathrm{km}^{2}$ (AUTRY, 1997) which could be crossed on foot in one day. The polity was headed by a hereditary royal family that ruled from a palace located in one of the city-state's communities over noble and commoner classes and slaves residing within the domain (CHANCE, 1982:34; LIND, 2000; OUDIJK, 2002; SPORES, 1984). It was common practice for the city state's sovereign to try to expand his or her territory, wealth and renown through a strategy of alliance with the royal families of other city-states (POHL AND BYLAND, 1994). Alliances were initiated and cemented among royal families by the exchange of marriage partners and probably sumptuary goods as well. Such alliances served to launch wars of conquest against rivals whereby a defeated city-sate paid tribute in goods and services to the victors. Alliances among city-states were largely ephemeral as they often dissolved upon the death of marriage partners (JOYCE, 2010: 44-45). As a 
result, the exercise of political power was for the most part circumscribed so that a city-state alliance was rarely able to perpetuate its power through time and space; exceptions to the rule include the Tututepec state in Oaxaca (SPORES, 1993), the Mexica Triple Alliance of the Central Basin which was expanding towards Oaxaca and the Isthmus at the end of the fifteenth century (HASSIG, 1988) and the Purépecha or Tarascan state of western Mexico (EVANS, 2004: 434-437). Codices, lienzos, and tiras and other Colonial period documents hint at the existence of extensive networks of city-state alliances during the early $16^{\text {th }}$ century linking royal families throughout the area extending from the Isthmus of Tehuantepec in southern Oaxaca to Tlaxcala in central Mexico (OUDIJK, 2000; POHL, 1994; 1999). This introduction provides a context for considering aspects of production, distribution and the use of the mosaic objects treated below.

\section{MATERIALS ANALYZED}

Masks, shields and rectangular plaques with turquoise, greenstone and shell mosaics affixed to wooden backings have been found in several Late Postclassic period archaeological sites in north and central Oaxaca extending from the Sierra Mazateca in the north to the Valley of Oaxaca at the geographical center of the state (Figure 1). 


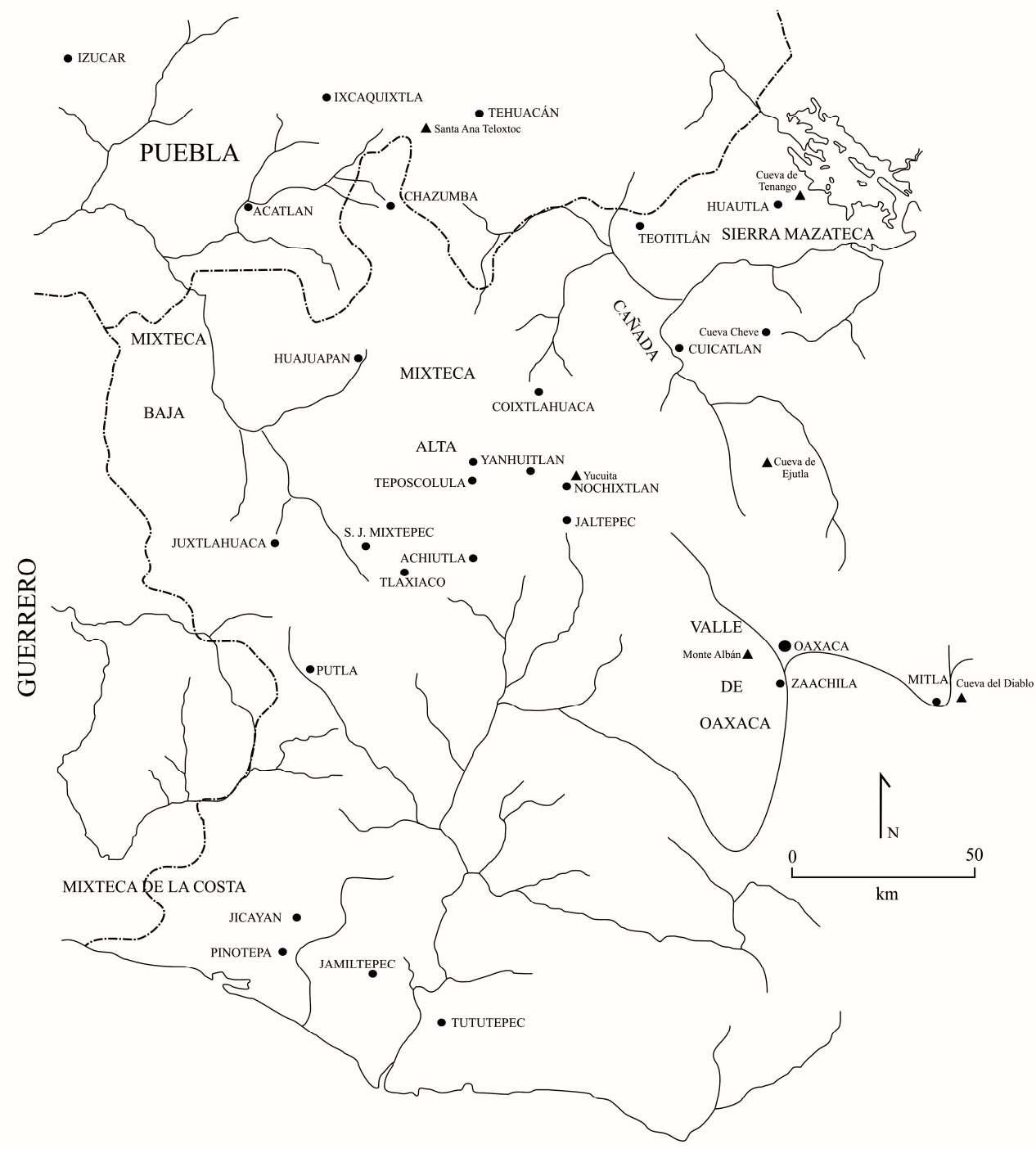

Figure 1. Map of places in Oaxaca and neighboring states mentioned in the text. Prepared by Ismael Vicente Cruz. 
Leaving aside for the moment, but discussed later, the unique items with turquoise mosaic decoration found in Tomb 7 at Monte Albán and in Tombs 1 and 3 at Zaachila, the masks, shields and plaques considered in this chapter include the following items and proveniences:

\section{Masks (Figure 2)}

La Cueva de Ejutla. This cave is located in the Mixteca region where Mixteco is today spoken but at the time of the conquest the area lying between the Jayacatlán and Tomellín Rivers appears to have been occupied by speakers of Cuicateco who were resettled elsewhere by the Spaniards around 1600 (VAN DOESBURG, 2001: 125-126). This example includes what was originally identified as an earspool and a spindle whorl.

Zaachila. (Zapotec region). Three masks from tombs 1 and 2 in Zaachila are similar to those from northern Oaxaca (GALLEGOS, 1978; WINTER, 2001: 4244). Two have an enclosed mouth, in contrast to the examples from Cueva Cheve and the Cueva de Ejutla which have mouths open at the bottom. One represents a jaguar with round eyes and conserves one long sharp canine tooth. 


\section{CUEVA CHEVE, (CUICATEC REGION)}
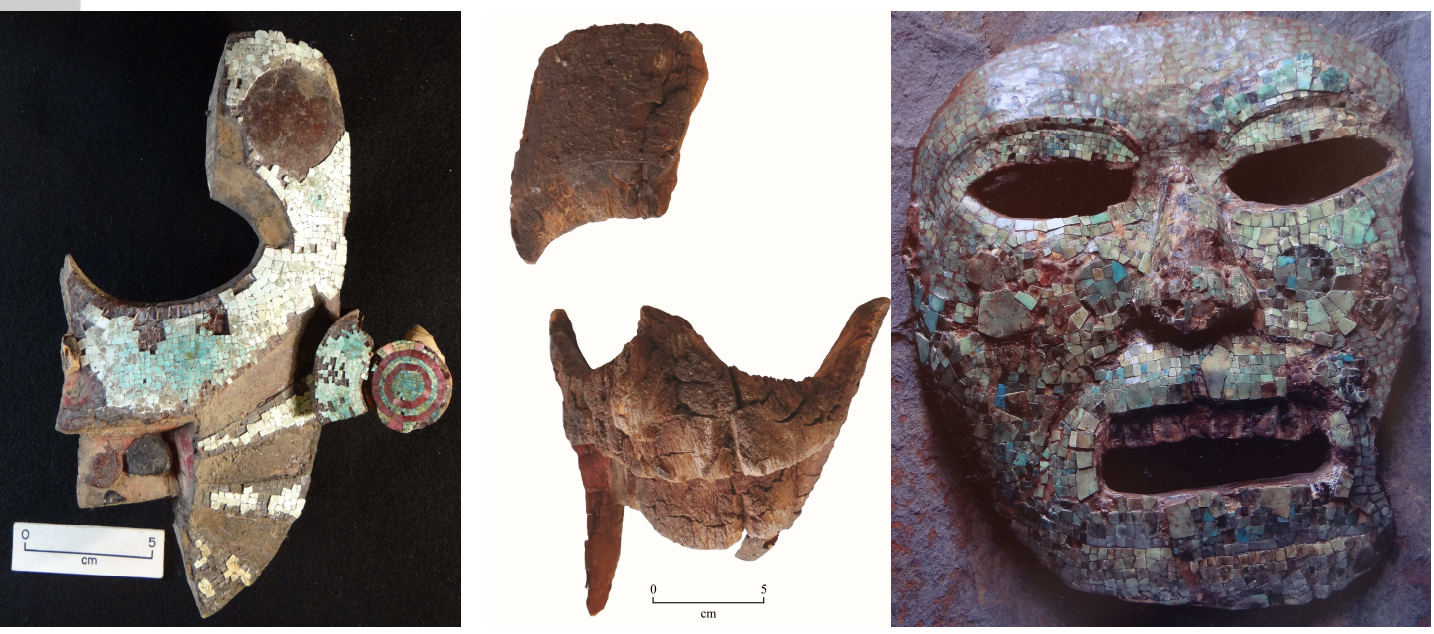

Figure 2. Masks from the Cueva de Ejutla (a); Cueva Cheve (b), and Tomb 1, Zaachila (c).

\section{DISCS (Figure 3)}

Jorge Acosta (1972) found a gold disc with bands of turquoise mosaics in Tomb 3 at Zaachila. A small disk with shell and turquoise mosaics and a small mask covered with flat mosaics as well as some rounded pieces (GALLEGOS, 1978; WINTER, 2001: 40) come from Tomb 1. While these artifacts display turquoise mosaics, like the masks, shields and plaques, they are unique and may not fit the same patterns we discuss for the other group. 
UNIVERSIDADE

FISTERAL https://periodicos.ufpe.br/revistas/clioarqueologica

clioarqueologica@ufpe.br

Clio Arqueológica 2020, V35N2, p.152-189, MARKENS; WINTER, LOPEZ DOI: 10.20891/clio.V35V2p152-189

Figure 3. Mosaic disk from Tomb 1, Zaachila. Taken from Winter (2001: Figure 43). 


\section{SHIELDS (Figure 4)}

Cueva Cheve. (Cuicatec region)

Cueva de Tenango (Mazatec region)
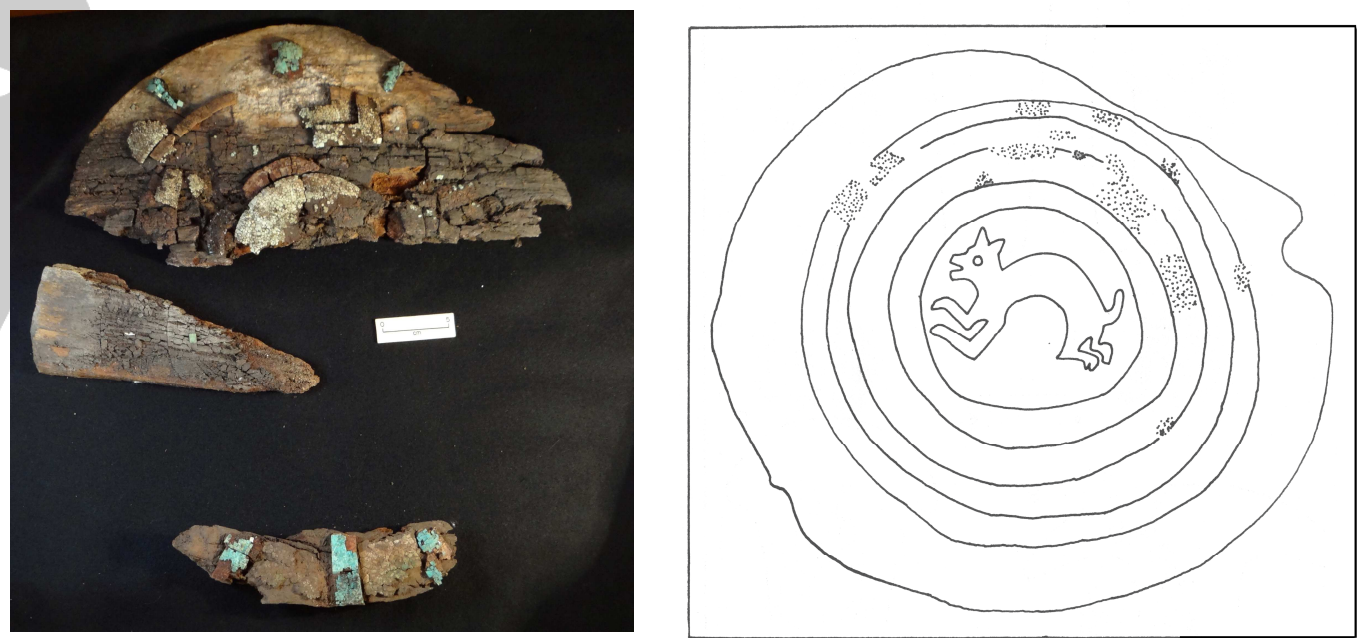

Figure 4. Mosaic shields: Cueva Cheve (a) and Cueva de Tenango (b). (Photograph by Cira Martínez López and drawing taken from WINTER 1990: Figure 84).

\section{RECTANGULAR PLAQUES}

Cueva Cheve. (Cuicatec region)

Artifact type not identified

Loose tesserae have been found at two sites; the backings had disintegrated.

Cueva del Diablo near Mitla (Zapotec region). A jadeite earspool found in the same area as the mosaic fragments may indicate the mosaics correspond to a mask.

Yucuita in the Nochixtlán Valley (Mixtec region). 
In this text we describe the production of these artifacts including the materials used, the distribution of the artifacts, their functions and the possible mechanisms through which the objects were exchanged. We also note some patterns which help to document Late Postclassic city-states in southern Puebla and north central Oaxaca.

In addition to the kinds of artifacts listed above, Alfonso Caso (1969) found some unique items in Tombs 7 with turquoise mosaics: a skull covered with mosaics, a carved bone weaving tool with mosaic inlays, two other bones with pieces of turquoise, and a gold disc with turquoise mosaic inlays. (Figure 5) A lot of loose tesserae were once displayed with other materials from Tomb 7 in the Oaxaca Regional Museum; they may have fallen off the skull or a bone object. Caso also reported turquoise beads from the tomb.
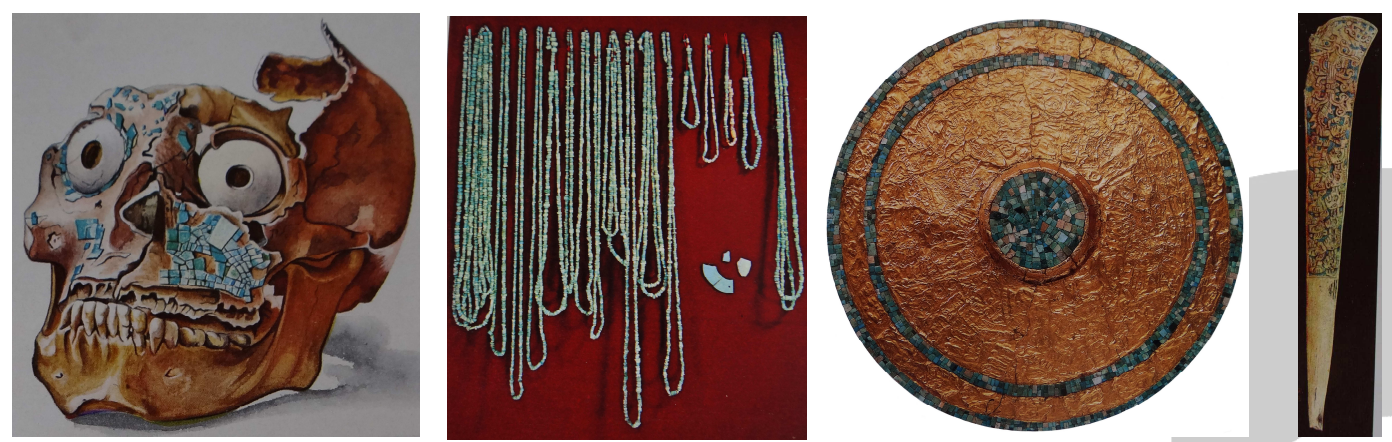

Figure 5. Mosaic inlayed skull from Tomb 7 Monte Alban (a). Taken from Caso 1969: Lámina IVA. Necklace made of Turquoise pieces, Tomb 7, Monte Albán (b). Taken from Caso 1969: Lámina XXXV. Gold and turquoise disk, Tomb 1 Zaachila (c). Taken from Winter 2001: Figure 2. Engraved bone Tomb 7 Monte Albán. Taken from Caso 1969: Lámina XXXVII. 


\section{OBJECT PROVENIENCES}

The sites of Monte Albán and Zaachila are well known to Mesoamerican archaeologists and the objects with turquoise mosaics have been published (CASO, 1969; WINTER, 2001). As noted, the objects from Monte Albán's Tomb 7 are not of primary concern here and do not fit the patterns we define for the other objects.

Cueva de Ejutla. This site is a small dry cave in the municipality of Nacaltepec. It may have been discovered and looted in the 1930s when the Oaxaca-Cuicatlán road was constructed. The site was reported by a custodian of the Mexican National Institute of Anthropology and History and visited in the 1960s by Kent $\mathrm{V}$. Flannery and his assistants. The mask fragments were recovered at that time. Chris L. Moser, a member of Flannery's project, inventoried the objects and believed that the masks with turquoise mosaics in the Heye Foundation in New York (now in the Smithsonian) came from the cave (MOSER, 1975).

Cueva Cheve. This is a large and deep cave in the mountains high on the east side of the Cañada in the municipality of Santos Reyes Pápalo. Visits by speleologists in the 1990s led to discovery of the wooden plaques which was reported to M. Winter by Janet Fitzsimmons (STEELE AND SNAVELY, 1997). The plaques, mask and shield, along with other objects, were recovered during a salvage project (GONZÁLEZ AND MÁRQUEZ, 1994). 
Cueva de Tenango. This large cave was discovered in 1983 by a young man in the town of San José Tenango. The wooden shield was one of several hundred objects recovered from the cave.

Cueva del Diablo. This cave near Mitla is used frequently today as a ritual place. The tessarae and green stone ear spool were recovered in 2006 during excavations carried out as part of the Proyecto Salavamento Arqueológico Carretera OaxacaIstmo (WINTER, 2008).

Yucuita. The Yucuita site near Nochixtlán in the Mixteca Alta is a well-known site in the town of the same name that has been occupied continuously since the Cruz A phase at 1400 B.C. The tessarae were found in a salvage excavation in 1993; the local priest insisted that the material be left in the town and no followup has been done since then.

\section{MATERIALS AND PRODUCTION}

In 2012 Emiliano Melgar and Reyna Solís Ciriaco examined the objects found in the Cueva de Ejutla, the Cueva Cheve and the Cueva del Diablo and took images of UV and IR Fluorescence on the mosaics in order to identify the minerals. Their analyses have shown, first, that the mosaic materials on the Cueva de Ejutla and Cueva Cheve objects is chemical turquoise, probably from Arizona, New Mexico and/or Sonora; and second, that the loose tesserae from the Cueva del Diablo are similar to sources employed in Chalchihuites, Zacatecas (Figures 6 and 7). 


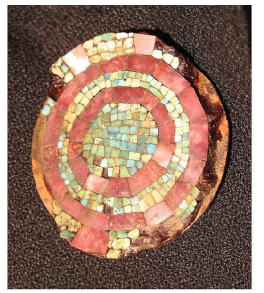

Visible light
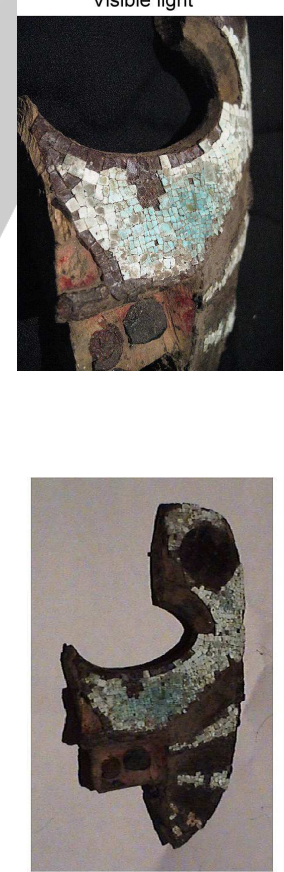

Visible light

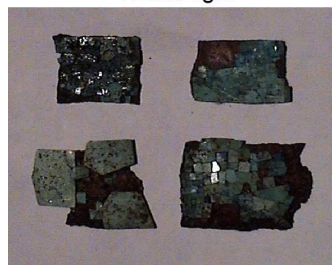

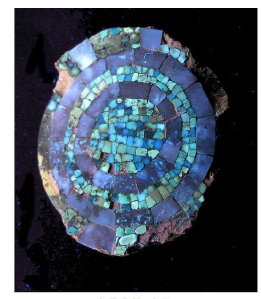

UV light

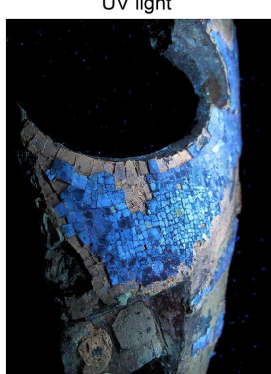

Figure 6. Ultraviolet fluorescence of mask and earspool from Cueva de Ejutla. Photograph by Emiliano Melgar Tísoc.

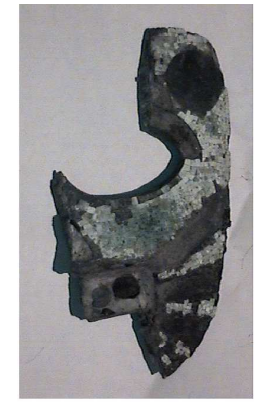

IR light

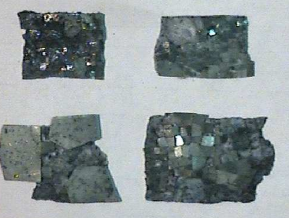

Figure 7. Infrared image analyses of mask from Cueva de Ejutla and shields from Cueva Cheve. Photograph by Emiliano Melgar Tísoc. 

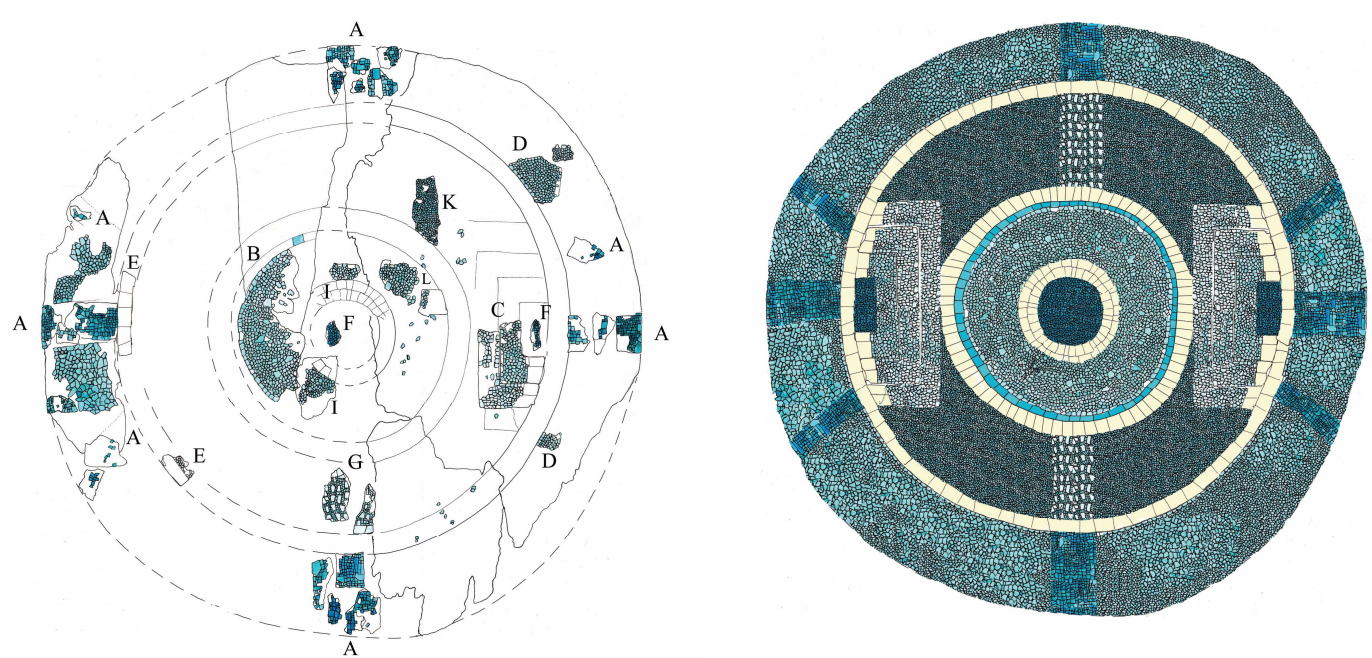

Figure 8. Shield from Cueva Cheve: Shield as found (a), and reconstruction. Drawings by Phillipe Cottenier.

While preparing illustrations of the materials in our archaeological laboratories in Cuilapan, scientific illustrator Philippe Cottenier made several interesting discoveries and observations about the production of the objects with turquoise mosaics (Figure 8):

1-In the case of the shield from Cueva Cheve, the tesserae were classified by color before affixing them to the backing, since the designs are based in part on color;

2-Again in the case of the Cueva Cheve shield, the tesserae were glued to some kind of thin backing material in sections and these sections were then placed on and glued to the wooden backing. This is evident because some of the sections came off the backing 
after the objects were deposited, notably in the case of the mask from Cueva Cheve. The mask was partially burned, the wooden backing seems to have shrunk, and the sections came off in strips;

3-Two objects (Figures 9 and 10) with mosaics from the Cueva de Ejutla, initially identified as an ear spool and a spindle whorl, are not individual artifacts but are part of an hour-glass-shaped ear spool that was fastened to and stuck out from the mask. The "spindle whorl" covered the distal (exterior) end of the ear spool;

4-The masks from the two sites are very similar in features including teeth, recessed mouth, and beveling around the eyes. The masks have a curved shape in horizontal cross-section;

5-The wooden backings which have lost some of the mosaics show that the designs were first outlined and carved on the backing, and the tessarae were added later. The tessarae were selected by color to fill section on the backing. (In the case of the gold disc from Zaachila the tessarae do not appear to have been selected by color.) In the case of the masks, even the teeth were outlined or carved before being covered by mosaics. This is evident from the objects which have lost some of the mosaics. The teeth are missing in our examples but were presumably made of white shell, as in similar objects. 

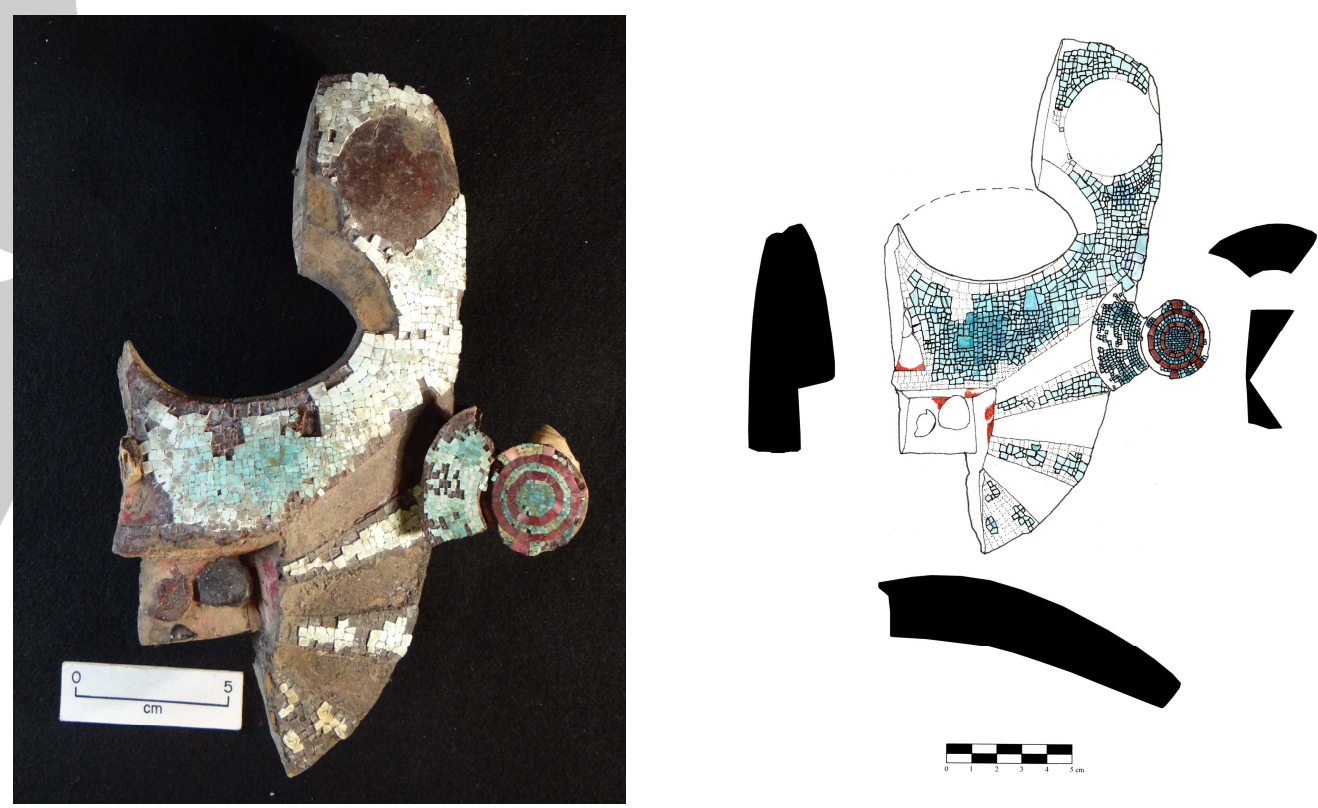

Figure 9. Mask from Cueva de Ejutla: Mask as found (a) and drawing (b). Photograph by Cira Martínez López and drawing by Phillipe Cottenier.

The discovery in 1986 of 54 wooden objects in the Cueva de Santa Ana Teloxtoc about $23 \mathrm{~km}$ southwest of the city of Tehuacán, Puebla, provides a key to understanding the production of the turquoise mosaic artifacts (VARGAS, 1989) (Figures 11 and 12). It is possible that the artifacts may have been placed in the cave as offerings and were found next to the cave walls as if they had formed parts of bundles. If so, these may have been ritual but not mortuary bundles since only one human bone was found in the cave. Some of the artifacts from the cave appear to be incomplete and unfinished which suggests that the cave may have 
served instead primarily as a hiding place for finished and unfinished mosaic pieces as a result of the Spanish incursion in the $16^{\text {th }}$ century. One of the wooden masks is painted rather than decorated with mosaic inlays; Gallegos Ruíz (1978: 87) found the remains of a similarly painted mask accompanying the principal burial in Tomb 1 at Zaachila.

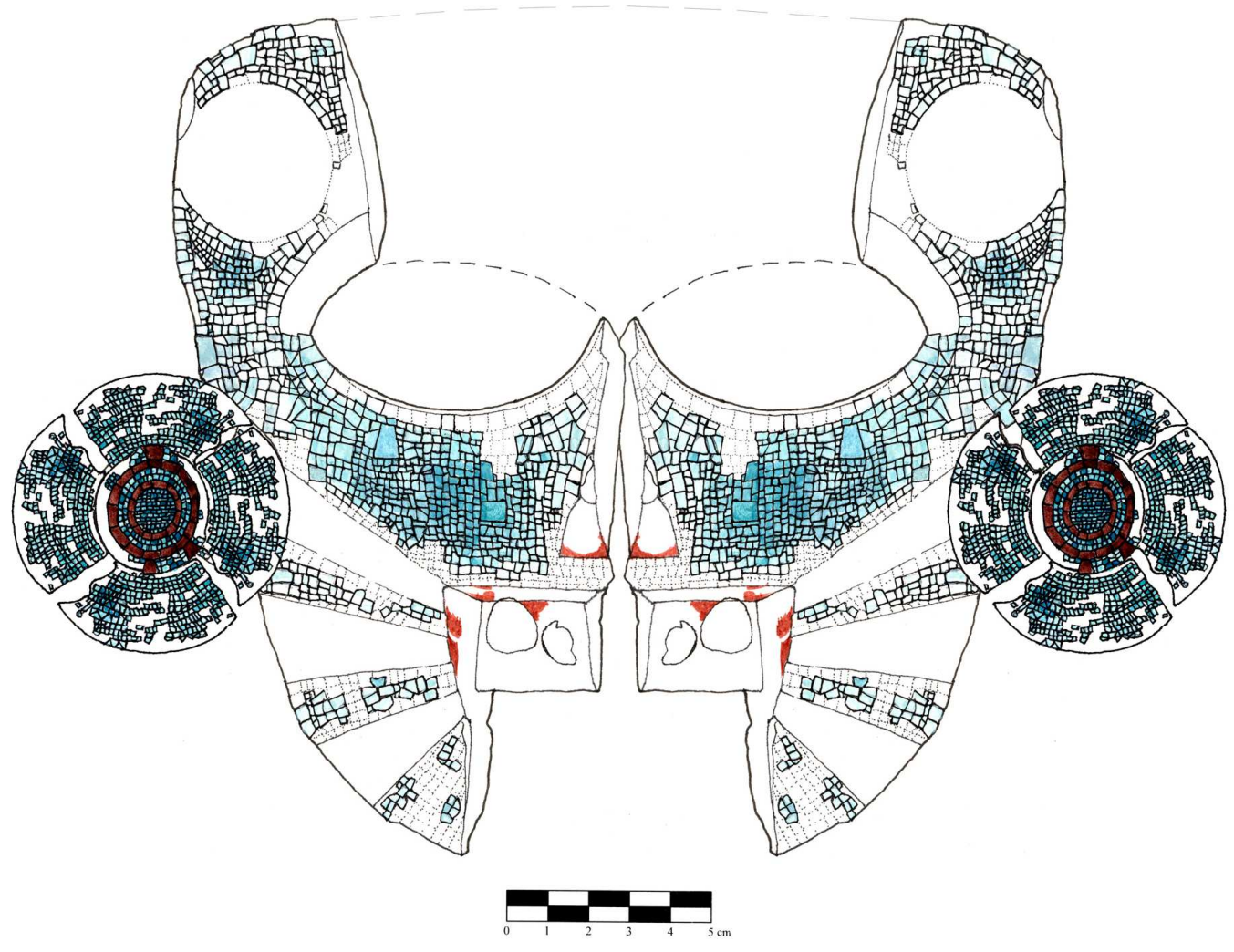

Figure 10. Reconstruction of mask Cueva de Ejutla. Drawing by Phillipe Cottenier. 
The quantity of wooden artifacts and the different stages of completion suggest that the objects were produced in a nearby community, though we have no information on other archaeological sites in the immediate area. The wood was prepared, the designs drawn and incised or carved on the wooden backing and the mosaic pieces then glued to the backing. The wood may have been obtained locally. In many cases the preferred wood for mosaic objects was cedar, Cedrela odorata, because of its insect-resistant properties (MCEWAN, et al. 2006: 34). The mosaic pieces on the other hand are not local and it is unclear how or from whom they were acquired.
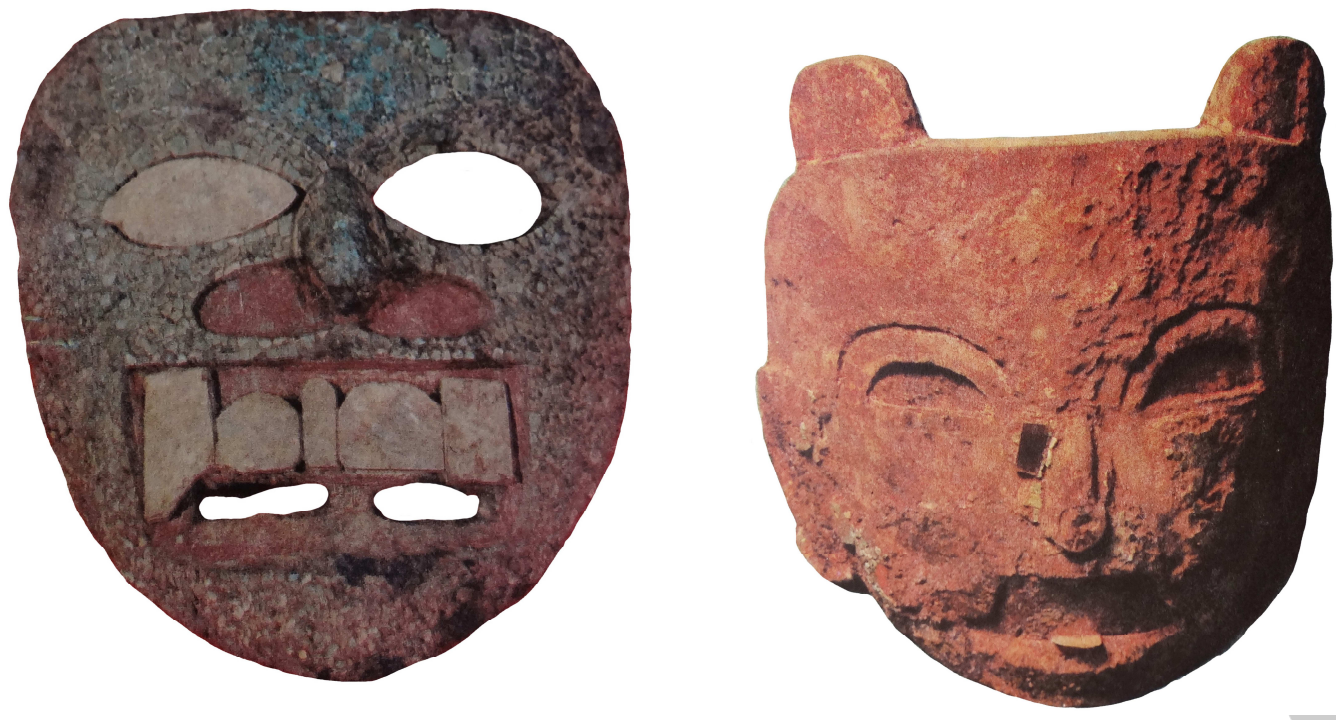
Figure 11. Masks from Santa Ana Teloxtoc. Taken from Vargas (1989: Figure 1 and 4).
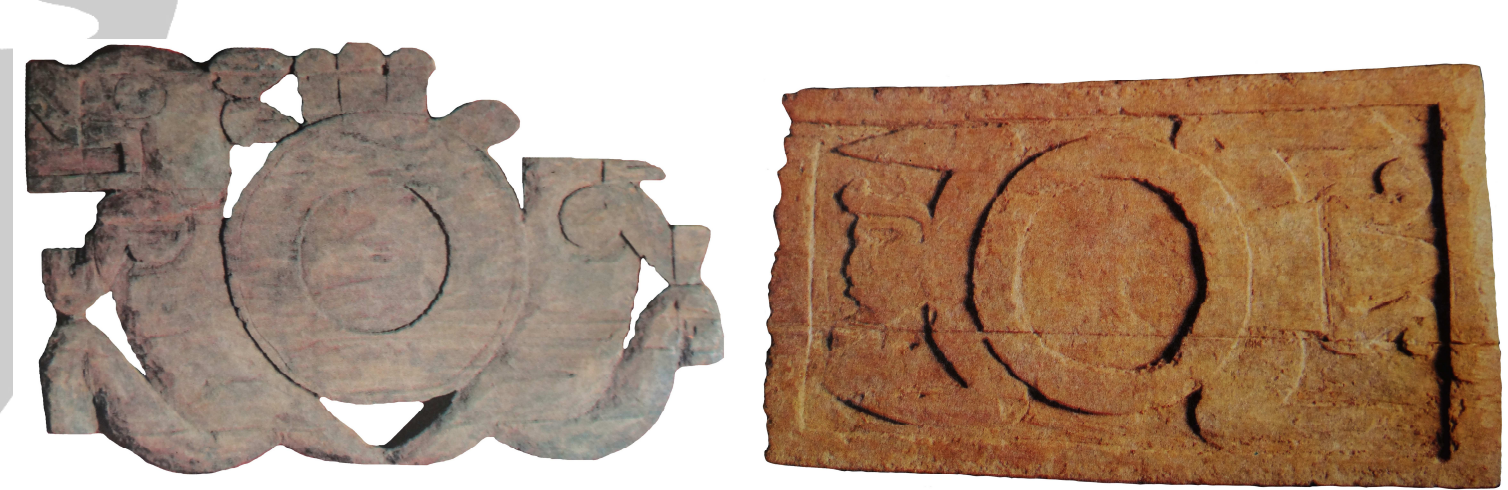

Figure 12. Unfinished wooden plaques from Santa Ana Teloxtoc. Taken from Vargas (1989: Figure 7 and 8).

The objects found in Oaxaca are relatively rare and all were finished pieces which contrasts with those found in the Cueva de Santa Ana Teloxtoc where both finished and unfinished pieces may have been intentionally hidden away. If so, this would suggest that Santa Ana Teloxtoc was an important regional center of mosaic artifact production. Further, there is no evidence that the Oaxaca mosaic pieces were made locally, and it seems more likely that they were acquired through exchange. For example, the wooden plaque backing (without tesserae) designated Object 20, a "tabla rectangular," is almost exactly the same size (34.3 
$\mathrm{x} 13.5 \times 1.9 \mathrm{~cm}$ ) as the two plaques found in the Cueva Cheve. Some of the masks have precisely the same configuration as the Oaxaca pieces.

Santa Ana Teloxtoc is in the Popoloca region of Puebla. We hypothesize that the objects reported here and found in Oaxaca were made in the workshop near Teloxtoc (and Tehuacán) and distributed to neighboring groups. This would include, as shown on the map (Figure 13), other groups of the Oto-mangue language family--the Mixtec and Cuicatec and Zapotec regions to the south and the Mazatec region to the southeast. Classic period antecedents of these Late Postclassic mosaic artifacts may be examples known from Teotihuacan and possibly produced in the same southern Puebla (Ñuiñe) region. 


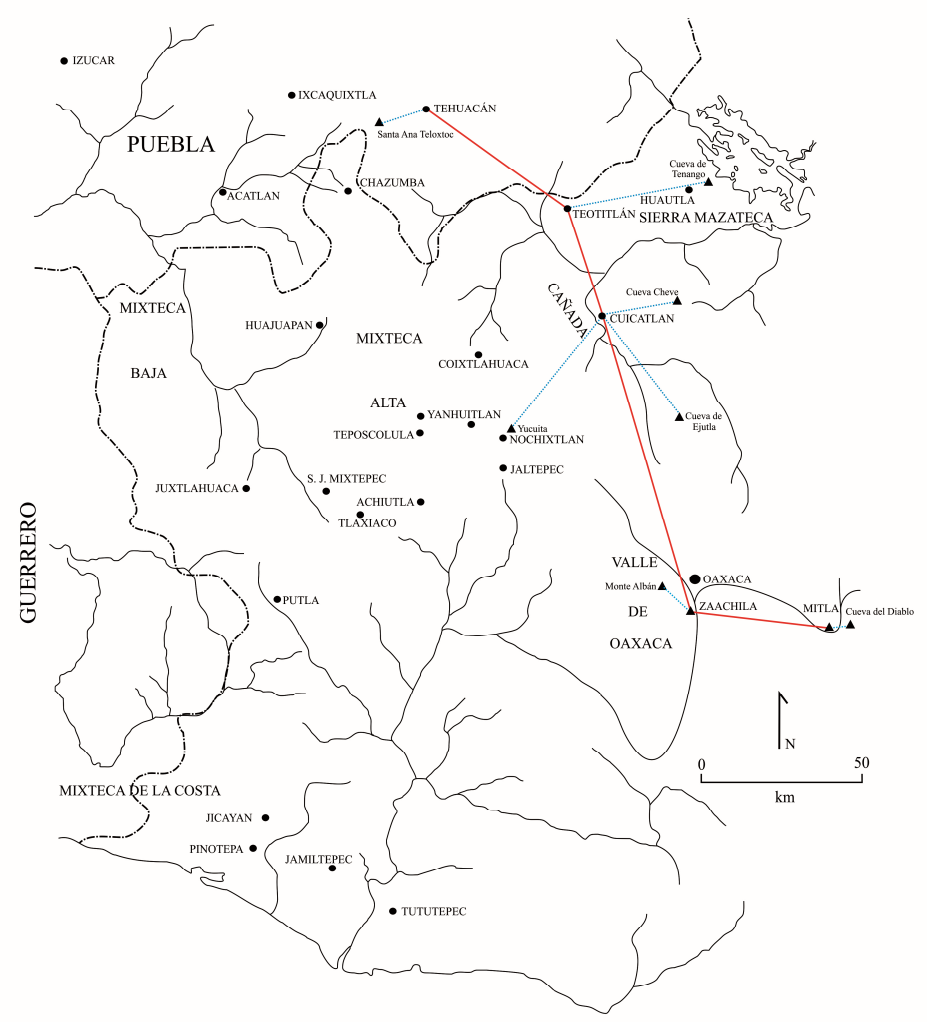

Figure 13. Map of possible exchange sphere of mosaic objects made in Santa Ana Teloxtoc.

\section{FUNCTIONS OF THE MOSAIC OBJECTS}

Masks. The use of masks has a long history in Mesoamerica (Figure 14). Carved stone masks in the La Venta Olmec Horizon (900-400 BC) found at Río Pesquero may have been fastened to bundles or placed over the faces of the dead. Stone masks also occur at Teotihuacan and may have been used with funerary bundles. 


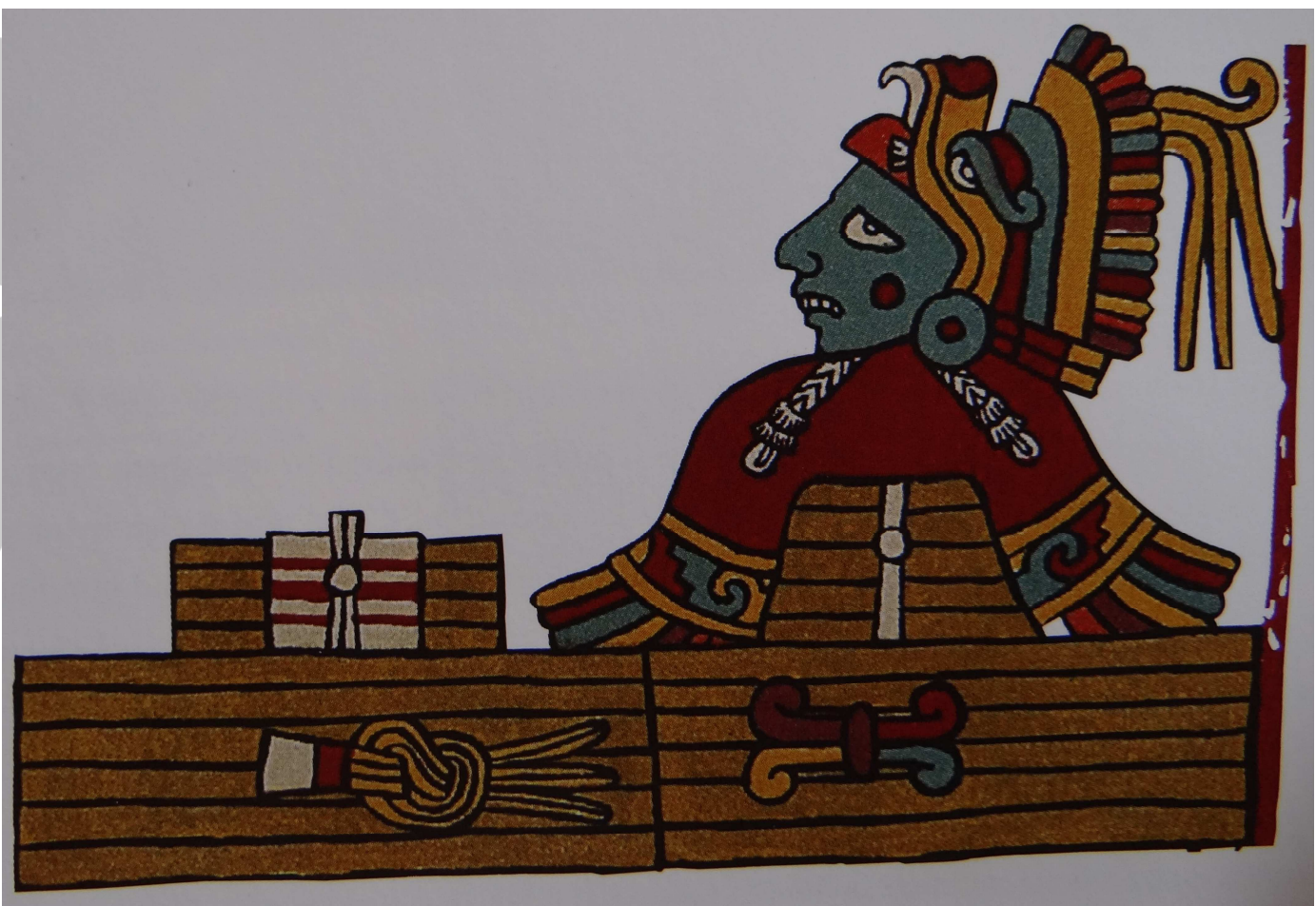

Figure 14. Human mortuary bundle with mask. Codex Nuttall. Taken from Nuttall, (1975: 82).

Veneration of bundles that represented gods is recorded in the early $16^{\text {th }}$ century from the southern Basin of Mexico (Figure 14). The mosaic masks found in the Cueva de Ejutla and Cueva Cheve may have been fastened to funerary or deity bundles, which were later defiled. In both cases the masks were found moved from their original context, broken and burned. Moser, as noted above, thought that the Heye Foundation masks were placed on bundles; few human bones were 
found in the Cueva de Ejutla so one wonders what may have happened to the bones if the bundles were looted. It is notable that in the other caves masks were not common, which may mean that they were used only for bundles associated with the highest nobility. Images from the codices show masks placed on mummy bundles. Did these contain the remains of actual individuals or were they sacred bundles with other contents?

Shields. The shields are light weight and highly decorated. They may have been used in ritual context. It is interesting that the shields painted on the walls at the Tehuacán Viejo site near Tehuacán are similar in format. The significance of both the painted shields and the wooden shields with mosaics is not clear.

Plaques. We have no direct evidence for the function of the plaques. The plaques from the Cueva Cheve when found by the speleologists had split in half, possibly from natural causes, and had been placed carefully in a crevice in the rock at the side of the cave above eye level. They probably would have been in disintegrated condition if left on the cave floor. The examples from Santa Ana de Teloxtoc include one large example, two others about $18 \mathrm{~cm}$ long and a fourth example with carved with a jaguar in profile and a circle in the center. 


\section{DISTRIBUTION (ALLIANCE CORRIDORS)}

The objects described here occur among groups of the Otomangue language family in central and northern Oaxaca into southern Puebla. Another group of artifacts with turquoise mosaics comes from central Mexico and include eight of the nine pieces in the British Museum described, analyzed and published by Colin McEwan (2006) and his colleagues. One object in that collection, the shield, is similar to the Puebla-Oaxaca artifacts; the others show different forms, more varied mosaics in terms of color and more rounded edges and three-dimensional carving (for example, the knife handle and the serpent). The shield has a band around the exterior free of mosaics and perforated with small, evenly spaced holes, possibly for attaching strings tied to feathers. The shield from San José Tenango has similar holes.

The differences in these two groups may reflect production at two different workshops, one in the Tehuacán area and another perhaps in Tenochtitlan as Melgar and colleagues proposed for the later site (MELGAR AND SOLÍS, 2010; VELÁZQUEZ, 2012). Objects from the former may have been exchanged to the south while objects from the latter remained in the Basin of Mexico.

The turquoise mosaic objects were luxury items, as were polychrome pottery, fancy textiles, gold and other metal ornaments and the pictographic manuscripts, made and used mainly by the Late Postclassic elite. These often reflect the Postclassic International Style present widely in Mesoamerica at the time and 
exchanged among the royal families who headed the city-states and governed over their respective classes of subordinates, from second level nobles, to commoners and slaves.

John Pohl (2003) has discussed Late Postclassic alliance corridors in which agreements among governing families, reinforced through exchange of specialized goods, linked royal families in various regions over wide areas. A possible alliance corridor based on the distribution of the turquoise mosaics may have linked Tehuacán with other important city-states to the south--Teotitlán, Cuicatlán, Zaachila and Mitla. Some items may have been traded to elites in smaller, related, possibly dependent communities. The objects may have had various functions among their elite owners, but eventually they ended up being deposited in ritual caves and tombs.

\section{ELITE BURIAL, MOUNTAINS OF SUSTENANCE AND MOSAIC OBJECTS}

Although objects with mosaic inlays were surely displayed and used in a wide variety of contexts during Oaxaca's pre-Hispanic past, archaeologists find them in places that favor their preservation, namely in masonry tombs installed in palaces and temples and as offerings in caves where they sometimes accompanied burials. As caves and tombs were spaces where deceased individuals were laid to rest, it seems reasonable to assume that these places shared some meanings in the minds 
of pre-Hispanic peoples. These meanings provide a useful frame of reference for considering some of the ways these mosaic objects may have been used.

The insights of Alicia Barabas (2006), Johanna Broda (1989), Doris Heyden (1989) and Alfredo López Austin (2002) among others establish that the significance of caves is tied to a wider geographical and symbolic frame of reference among traditional peoples today, as well as their pre-Hispanic ancestors. Those caves that contain water and are also located in the side of a mountain or hill constitute a long enduring symbolic complex in ancient Oaxaca and Mesoamerica stretching back to the Middle Preclassic period (SCHELE AND GUERNSEY, 2001). Together, they represent a "Mountain of Sustenance" or storehouse believed to contain the natural resources that sustain the community: water, plants and animals. Further, it is also a common belief today that the Mountain's bounty is the property of a Dueño or Owner, a supernatural being dwelling within the mountain and to whom one appeals for success when undertaking farming, hunting or other procurement activities (STALLER AND STROSS, 2013: 157-160; VOGT, 1970: 6). In addition, the Mountain of Sustenance is often considered the place of community origin and in some cases ethnic origin as well. Just as it is a place of human origin, it is also the place where the souls of the community's dead reside in eternity.

As the paradigm of the Mountain of Sustenance occupies a central place in the Mesoamerican worldview, it appears to have been materialized in the cultural landscape of both religious and domestic architecture in Oaxaca and Mesoamerica 
(MARTÍNEZ et al., 2014: 9-16). Outstanding examples include the twin temples of the Templo Mayor in Tenochtitlán, built by the Aztecs in 1325 and thereafter enlarged until the conquest (LÓPEZ AND LÓPEZ, 2009). The twin temples were called the "Tonacatépetl," or the Mountain of Sustenance (BRODA, 1989: 40). Other temples configured as Mountains of Sustenance include the Great Pyramid of Cholula which is illustrated in the Relación Geográfica 1580 with currents of water flowing from its base (OUDIJK, 2008: Figure 3.3). Similarly, the Feathered Serpent Temple at Teotihuacan is decorated with sculptures of serpents often associated with the Mountains of Sustenance among contemporary traditional peoples.

Several palaces at Monte Albán and other centers in the Valley of Oaxaca came to incorporate architectural elements in their design during the Classic and Postclassic periods normally associated with temples (MARTÍNEZ et al., 2014: 9). These were built on a pyramidal base furnished with a wide staircase which in turn was sometimes framed on both sides by wide balustrades. Well preserved examples include the palace on top of Structure $\mathrm{L}$ and the Palacio Este in the Main Plaza of Monte Albán, the sixth and final palace built on Structure 195 at Lambityeco, the second palace on Mound A at Zaachila and Mound 35 at Macuilxóchitl (GALLEGOS, 1978; MARTÍNEZ et al., 2014: 9; WINTER, 2008).

If the interpretation is valid that some temples and palaces were built as replicas of Mountains of Sustenance, then it follows that first, the tombs found within are analogous to caves and second that the deceased rulers buried within the tomb are 
associated with the symbolic natural resources stored within the pyramid. In other words rulers were equated with or in some way linked to what contemporary peoples perceive today as the Dueño or Owner of the mountain's essential resources. The practice and significance of placing the palaces of rulers on top of a pyramid/Mountain of Sustenance during the Classic and Postclassic periods is also expressed in carved public monuments and funerary urns where it became by the Early Classic period a standard representation for individual occupying positions of authority and political power: the sovereign dressed as a jaguar standing or seated atop a pyramid/Mountain of Sustenance (MARKENS et al., 2013: 216).

Palace architecture and representations of rulers in sculpture suggest that sovereigns exerted control over the vital resources of water, plants and animals contained in the Mountain of Sustenance on which they resided or stood (MARKENS, 2013: 71). It is probably for this reason that elite tombs in palaces and in caves were visited time and again (LIND, 2002: 65) where the human remains contained within were apparently petitioned for a variety of things judging by the array of turquoise and other objects. Perhaps the turquoise and greenstone masks placed over the face of a deceased lord or attached to a mummy bundle served to give a countenance to the spirit of the dead lord to whom petitions were directed.

One petition in particular that today has no counterpart in the ethnographic record associated with caves is indicated by some of the turquoise and other objects 
found in Tomb 1 of Zaachila and Cueva Cheve: these are petitions related to warfare. The Relaciones Geográficas tell us that the Vuija Tao, "Great Seer," or high priest of Mitla during the sixteenth century regularly consulted the mummy bundles of valley kings under his care on issues of royal succession in the citystates of the Valley of Oaxaca (ACUÑA, 1984); disputes often resulted in warfare (Figure 15). In this vein, Lord 8 Deer Jaguar Claw is depicted in the ZoucheNuttall and Colombino Codices consulting with the Lady 9 Grass of Chalcatongo, a Mixtec counterpart to the Valley of Oaxaca Vuija Tao of Mitla, before undertaking his campaign of conquest on the Coast of Oaxaca (JOYCE et al., 2004; POHL, 1994). Lady 9 Grass was an oracle and custodian of Mixtec royal mummy bundles.

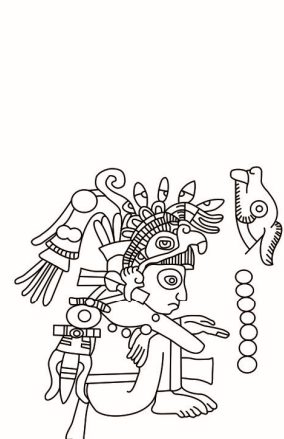

LORD 8 DEER

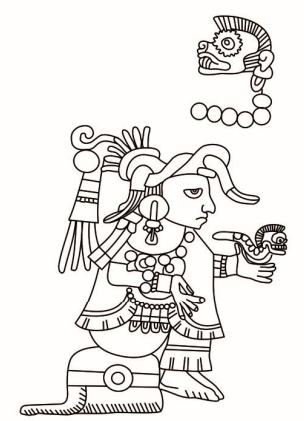

LADY 6 MONKEY

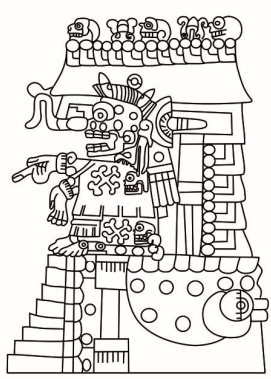

LADY 9 GRASS
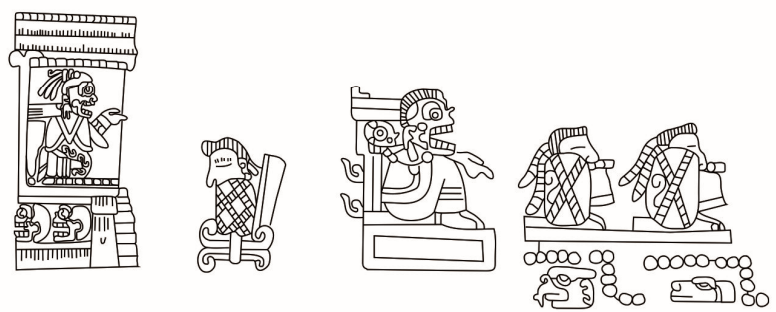

Figure 15. Top. Lord 8 Deer Jaguar Claw consulting Lady 9 Grass of Chalcatongo. Bottom. Lady 9 Grass of Chalcatongo consulting mummy bundles. 
Taken from (Pohl 1994:

Chart 3).

The petitioning of dead rulers for success in warfare finds expression in a unique tableau of clay figurines found in the patio of the palace of Tomb 103 at Monte Albán dating to the Late Classic period (SÁNCHEZ, nd). Urcid (2005) believes that the final palace built on top of a pyramid lost its residential function and served instead as a mausoleum dedicated to the cult of the founders of the lineage of rulers buried within.

The set of figurines found in the patio of the mausoleum consist of thirteen clay individuals that appear to be conducting a ritual in front of a masked mummy bundle, presumably a deceased ruler, who may have been buried in the structure (Figure 16). The five principal participants wear headdresses featuring images of owls and the Fire Serpent, both of which are symbols presaging war; three of them hold mirror-like objects which were used in rituals connected with warfare among the Mexica. Commoners in the group accompany the ritual by playing music. The turquoise jaguar mask, turquoise shields and jaguar claw vessels found in tomb 1 at Zaachila suggest that similar petitions took place there as well. Finally, the same petitions may have taken place in the Cueva Cheve cave where archaeologists found a high-status burial bundle with mask and sacrificial knives as well as a mosaic plaque in which warriors are portrayed taking captives and the playing the ballgame. 


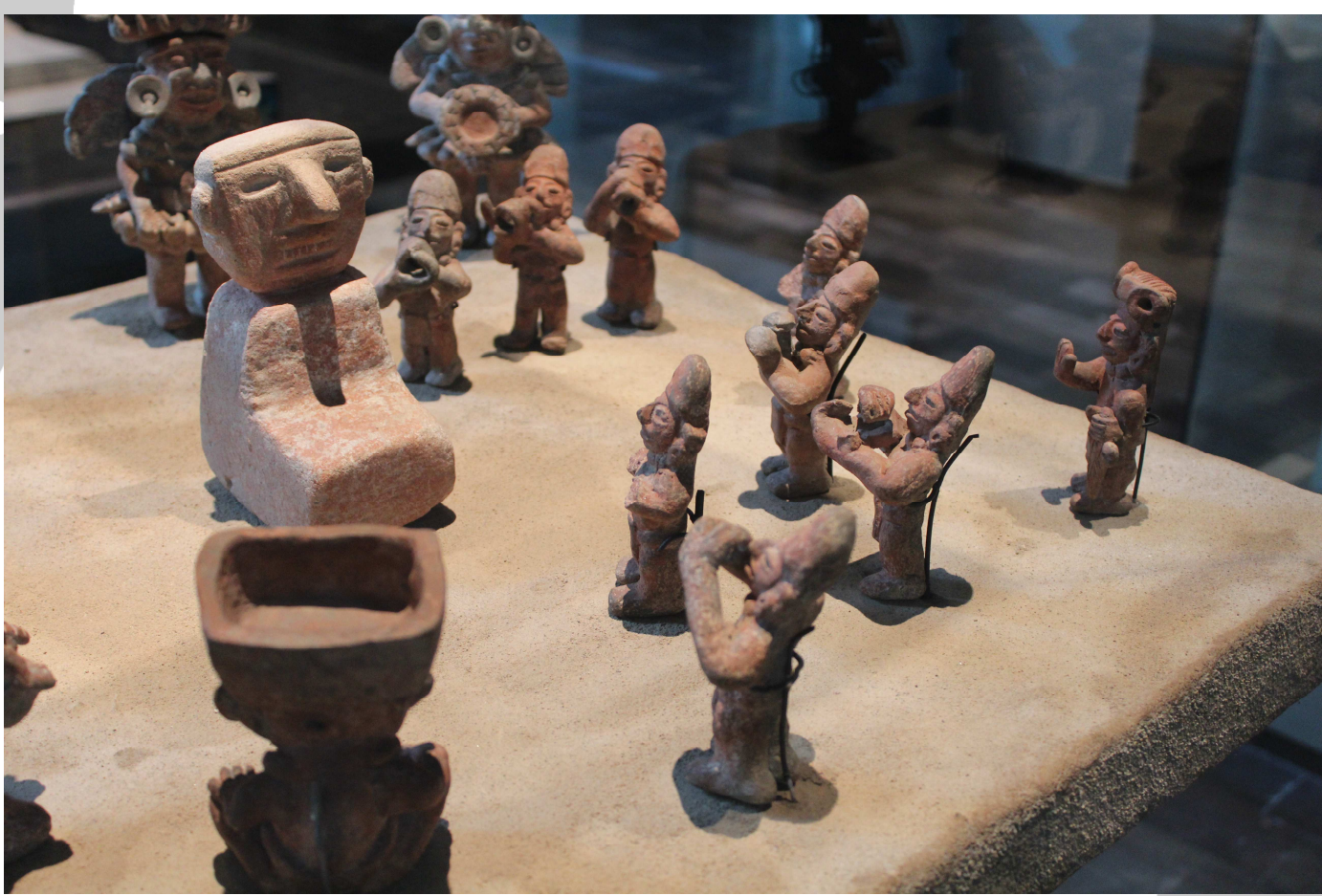

Figure 16. Figurines found in the patio of the residence of Tomb 103, Monte Albán. Photograph by Gonzalo Sánchez Santiago.

\section{CONCLUSIONS}

The Postclassic period mosaic artifacts from Oaxaca and the Cueva de Santa Ana Teloxtoc, Puebla, considered in this study point to a highly complex and 
specialized industry whose products were intended for principally for the noble class. The industry involved the acquisition of raw materials that were either scarce or available only at a great distance (MELGAR AND SOLÍS, 2010; POHL, 2012; WEIGAND et al., 1977); these include turquoise, greenstone and shell among other raw materials. These materials were channeled to specialized craft centers like the one that presumably existed in the proximity of the Cueva de Santa Ana Teloxtoc via long-distance exchange, or by members of a specialized merchant class or perhaps by tribute. The details remain unclear. Once the necessary materials were in hand, artisans at the production center near Santa Ana Teloxtoc made the objects which we hypothesize were subsequently distributed throughout the highlands of Oaxaca by means of gift exchange among the ruling elite; these objects may have played a role in the formation of alliances between royal houses of city-states occupying points along the alliance corridor. Additionally, some mosaic masks and similarly decorated items may have been acquired by the rulers of Oaxaca city-states by imposing tribute on vanquished rivals. We know of no Colonial documents indicating that these goods were available to the public at large in regional market centers. The presence of finished and unfinished mosaic artifacts in the Cueva de Santa Ana Teloxtoc and the near absence of burials there suggest that the cave was used to hide these prized objects from the Spaniards. 


\section{REFERENCES ${ }^{3}$}

ACOSTA, J. R. 1972. "Nuevos descubrimientos en Zaachila". Boletín del Instituto Nacional de Antropología e Historia, Época II (3), 27-34.

ACUÑA, R. 1984. Relaciones Geográficas del Siglo XVI: Antequera. Volumes I and II. Mexico City: Universidad Nacional Autónoma de México, Instituto de Investigaciones Antropológicas.

AUTRY, W. O. 1997. Methods to Derive Population from Suma de Visitas. Paper presented in the Fourth Mixtec Gateway Conference, Las Vegas.

BARABAS, A. 2006. Dones, dueños y santos: Ensayo sobre religiones en Oaxaca. Mexico City: Consejo Nacional para las Culturas y las Artes, Instituto Nacional de Antropología e Historia and Miguel Porrúa.

BOONE, E. H. 2000. Stories in Red and Black: Pictorial Histories of the Aztecs and Mixtecs. Austin: University of Texas Press.

BRODA, J. 1989. “Geografía, Clima y Observación de la Naturaleza en la Mesoamérica Prehispánica". In E. Vargas (ed.). Las Máscaras de la Cueva de Santa Ana Teloxtoc. Mexico City: Universidad Nacional Autónoma de México, 35-51.

CASO, A. 1969. El Tesoro de Monte Albán. Mexico City: Memorias del Instituto Nacional de Antropología e Historia 3.

CHANCE, J. K. 1982. Razas y Clases de la Oaxaca Colonial. Mexico City: Instituto Nacional Indigenista.

VAN DOESBURG, S. 2001. Códices Cuicatecos Porfirio Díaz y Fernández Leal. Vol. 1. Mexico City: Editorial Miguel Ángel Porrúa.

\footnotetext{
${ }^{3}$ The authors are most grateful to Emiliano Melgar Tísoc for his kind invitation to present an earlier version of this work in the symposium "Turquoise and Blue-Green Stones in the Southwest, Northern Mexico and Mesoamerica: Where mined, What produced, Who consumed?" organized by Emiliano Melgar Tísoc and Emiliano Gallaga Murrieta at the $78^{\text {th }}$ Society for American Archaeology Annual Meeting, Honolulu, Hawaii, April 3-7, 2013. We also thank Ismael Vicente Cruz for digitizing the figures and Phillipe Cottenier for the preparation of the drawings.
} 
ESCALANTE Gonzalbo, P. 2012. "The Mixteca-Puebla Tradition and H. B. Nicholson”. In M. A. Boxt and B. D. Dillon, (eds.). Fanning the Sacred Flame: Mesoamerican Studies in Honor of H. B. Nicholson. Boulder: University Press of Colorado, 293-307.

EVANS, S. T. 2004. ANCIENT MEXICO AND CENTRAL AMERICA: ARCHAEOLOGY AND CULTURE HISTORY. London: Thames \& Hudson.

GALLEGOS Ruiz, R. 1978. El Señor 9 Flor en Zaachila. Mexico City: Universidad Nacional Autónoma de México.

GONZÁLEZ Licón, E., and L. MÁRQUEZ Morfín. 1994. "Rito y ceremonia prehispánicos en las cuevas de la Cañada". In H. B. Nicholson and Eloise Quiñones Keber (eds.). Mixteca-Puebla: Discoveries and Research in Mesoamerican Art and Archaeology. Culver City: Labyrinthos, 223-234.

HASSIG, R. 1988. Aztec Warfare: Imperial Expansion and Political Control. Norman: University of Oklahoma Press.

HEYDEN, D. 1989. “Aspectos Mágico-religiosos de las Cuevas”. In Las Máscaras de la Cueva de Santa Ana Teloxtoc, Ernesto Vargas, editor, pp. 91-96. Universidad Nacional Autónoma de México, Mexico City.

JOYCE, A. A. 2010. Mixtecs, Zapotecs and Chatinos: Ancient Peoples of Southern Mexico. Malden: Wiley-Blackwell.

JOYCE, A. A., A. WORKINGER, B. HAMANN, P. KROEFGES, M. OLAND and S. KING. 2004. "Lord 8 Deer Jaguar Claw and the Land of the Sky: The Archaeology and History of Tututepec." Latin American Antiquity 15(3), 273-297.

LIND, M. 2000. "Mixtec City-States and Mixtec City-State Culture”. In M. Hansen (ed.). Comparative Study of Thirty City-State Cultures. Copenhagen: The Royal Danish Academy of Sciences and Letters, 567-580.

LIND, M. 2002. "Lambityeco - Tomb 6". In P. Plunket (ed.). Homenaje a John Paddock. Mexico City: Universidad de las Américas, 45-66.

LÓPEZ Austin, A. 2002. Breve Historia de la Tradición Religiosa Mesoamericana. Mexico City: Instituto de Investigaciones Antropológicas, Universidad Nacional Autónoma de México. 
LÓPEZ, A. and L. LÓPEZ. 2009. Monte Sagrado: Templo Mayor. Mexico City: Instituto Nacional de Antropología e Historia-Universidad Nacional Autónoma de México.

MARKENS, R. 2013. "El significado de la greca escalonada en la imaginería prehispánica de Oaxaca: Una base del poder político”. Cuadernos del Sur 18 (35), 67-81.

MARKENS, R., M. WINTER and C. MARTÍNEZ López. 2013. "El jaguar en la arqueología de Oaxaca". In A. Aquino, V. De la Cruz, M. Briones, A. Sánchez and M. Huerta (eds.), El jaguar en Oaxaca. Oaxaca: Gobierno del Estado de Oaxaca, Secretaría de las Culturas and Artes de Oaxaca, Instituto Nacional de Antropología e Historia and Universidad Autónoma "Benito Juárez" de Oaxaca, 212-213.

MARTÍNEZ López, C., M. WINTER and R. MARKENS. 2014. Muerte y vida entre los zapotecos de Monte Albán. Oaxaca: Centro INAH Oaxaca-Programa de Apoyo a las Culturas Municipales y Comunitarias.

MCEWAN, C., A. MIDDLETON, C. CARTWRIGHT and R. STACEY. 2006. Turquoise Mosaics from Mexico. Durham: Duke University Press.

MELGAR Tísoc, E., and R. SOLÍS Ciriaco. 2010. "Manufacturing techniques of the turquoise mosaics from the Great Temple of Tenochtitlan, Mexico". In J. L. Ruvalcaba Sil, J. Reyes Trujeque and A. Velázquez Castro (eds). 2nd Latin-American Symposium on Physical and Chemical Methods in Archaeology, Art and Cultural Heritage Conservation. Symposium on Archaeological and Art Issues in Materials Science, IMRC 2009. Mexico City: Sociedad Mexicana de Materiales-Instituto Nacional de Antropología e Historia-Universidad Nacional Autónoma de México-Universidad Autónoma de Campeche, 119-124.

MOSER, C. L. 1969. "La Tumba 1 del Barrio del Rosario, Huitzo, Oaxaca”. Boletín del Instituto Nacional de Antropología e Historia 36, 41-47.

MOSER, C. L. 1975. “Cueva de Ejutla: ¿una cueva funeraria postclásica?”. Boletín del Instituto Nacional de Antropología e Historia 14, 25-36.

NICHOLSON, H. B., and E. Quiñones Keber. 1994. "Introduction”. In H. B. NICHOLSON y E. QUIÑONES KEBER (eds.). Mixteca-Puebla: Discoveries in Mesoamerican Art and Archaeology. Culver City: Labyrinthos, vii-xv.

NUTTALL, Z., (ed.). 1975. The Codex Nuttall: A Picture Manuscript from Ancient Mexico. New York: Dover Publications. 
OUDIJK, M. 2000. Historiography of the Bènizàa: The Postclassic and Early Colonial Periods (1000-1600 A.D.). Leiden: Research School of Asian, African and Amerindian Studies, Universiteit.

OUDIJK, M. 2002. “The Zapotec City-State”. In M. Hansen (ed.). A Comparative Study of Thirty City-State Cultures. Copenhagen: The Royal Danish Academy of Sciences and Letters, 73-90.

OUDIJK, M. 2008. "The Postclassic Period in the Valley of Oaxaca: The archaeological and Ethnohistorical Records". In J. P. Blomster (ed.). After Monte Alban: Transformation and negotiation in Oaxaca, Mexico. Boulder: University Press of Colorado, 95-118.

POHL, J. M.D. 1994. The Politics of Symbolism in the Mixtec Codices. Nashville: Vanderbilt University Publications in Anthropology 46.

POHL, J. M.D. 1999. "The Lintel Paintings of Mitla and the Function of the Mitla Palaces". In J. K. Kowalski (ed.). Mesoamerican Architecture as a Cultural Symbol. New York: Oxford University Press, 176-197.

POHL, J. M.D. 2003. "Royal Marriage and Confederacy Building among the eastern Nahuas, Mixtecs and Zapotecs". In M. E. Smith and F. F. Berdan (eds.). The Postclassic Mesoamerican World. Salt Lake City: The University of Utah Press, 243-248.

POHL, J. M.D. 2012. “The Odyssey of the Plumed Serpent”. In V. Fields, J. Pohl and V. Lyall (eds.). Children of the Plumed Serpent: The Legacy of Quetzalcoatl in Ancient Mexico. London: Los Angeles County Museum of Art and Scala Publishers Limited, 94107.

POHL, J. M. D., and B. E. BYLAND. 1994. “The Mixteca-Puebla Style and Early Postclassic Socio-political Interaction”. In H. B. Nicholson and E. Quiñones Keber (eds.). Mixteca-Puebla: Discoveries in Mesoamerican Art and Archaeology. Culver City: Labyrinthos, 189-199.

ROBERTSON, D. 1959. Mexican manuscript Painting of the Early Colonial Period. The Metropolitan Schools. New Haven: Yale University Press.

SÁNCHEZ, G. nd. El Complejo Serpiente-Búho en los Silbatos Zapotecos del Periodo Clásico en el Valle de Oaxaca. Unpublished Manuscript. 
SCHELE, L. and J. GUERNSEY. 2001. "What the Heck's Coatépec?: The Formative Roots of an Enduring Mythology". In R. Koontz, K. Reese-Taylor and A. Headrick (eds.). Landscape and Power in Ancient Mesoamerica. Boulder: Westview Press, 29-53.

SMITH, M. E., and F. F. BERDAN (eds.). 2003. The Postclassic Mesoamerican World. Salt Lake City: The University of Utah Press.

SPORES, R. 1984. The Mixtecs in Ancient and Colonial Times. Norman: University of Oklahoma Press.

SPORES, R. 1993. "Tututepec: A Postclassic-Period Mixtec Conquest State”. Ancient Mesoamerica 4 (1), 167-174.

STALLER, J. and B. STROSS. 2013. Lightning in the Andes and mesoamerica: PreColumbian, Colonial and Contemporary Perpsectives. New York: Oxford University Press.

STEELE, J. F., and R. SNAVELY. 1997. "Cueva Cheve Tablet”. Journal of Cave and Karst Studies 59 (1), 26-32.

URCID, J. 2005. Zapotec Writing: Knowledge, Power and Memory in Ancient Oaxaca. Available on line at http://www.famsi.org/zapotecwriting/

VARGAS, E. (ed.). 1989. Las Máscaras de la Cueva de Santa Ana Teloxtoc. Mexico City: Universidad Nacional Autónoma de México.

VELÁZQUEZ Castro, A., M. E. MARÍN Benito, E. R. MELGAR Tísoc and R. B. SOLÍS Ciriaco. 2012. "The Turquoise Disk from Offering 99 at the Templo Mayor in Tenochtitlan". In J. C. H. King, M. Carocci, C. Cartwright, C. McEwan and R. Stacey (eds.). Turquoise in Mexico and North America. London: Archetype-The British Museum, 75-87.

VOGT, E. 1970. The Zinacantecos of Mexico: A Modern Maya Way of Life. New York: Holt, Rinehart and Winston.

WEIGAND, P. C., G. HARBOTTLE and E. V. SAYRE. 1977. "Turquoise sources and source analysis: Mesoamerica and the Southwestern U. S. A.”. In T. Earle and J. Ericson (eds.). Exchange Systems in Prehistory. New York: Academic Press, 15-34. 
WINTER, M. 1990. “Oaxaca Prehispánica”. In M. Winter (ed.). Lecturas Históricas del Estado de Oaxaca, Volume I. Mexico City: Instituto Nacional de Antropología e HistoriaGobierno del Estado de Oaxaca, 31-219.

WINTER, M. 2008. "Classic to Postclassic in Four Oaxaca Regions: The Mazateca, the Chinantla, the Mixe region, and the southern Isthmus". In J. P. Bloomster (ed.). After Monte Albán: Transformation and negotiation in Oaxaca. Mexico, Boulder: University Press of Colorado, 393-426.

WINTER, M. (ed.). 2008. Informe para el Centro SCT Oaxaca de la Secretaría de Comunicaciones y Transportes de los Proyectos Salvamento Arqueológico CarreteraIstmo (SACOI) y Salvamento Arqueológico Carretera Oaxaca-Istmo (SACOI) y Salvamento Arqueológico Carretera Salina Cruz-La Ventosa (SC-LV) Temporadas 20022008. Oaxaca: Manuscript on file, Centro SCT Oaxaca.

WINTER, M., and M. CARMONA. 2001. Tesoros de Oaxaca. Mexico City: Gobierno del Estado de Oaxaca. 